\title{
A Relaxed Eddy Accumulation (REA)-GC/MS system for the determination of halocarbon fluxes
}

\author{
K. E. Hornsby ${ }^{1}$, M. J. Flynn ${ }^{2}$, J. R. Dorsey ${ }^{2}$, M. W. Gallagher ${ }^{2}$, R. Chance ${ }^{1}$, C. E. Jones ${ }^{1}$, and L. J. Carpenter ${ }^{1}$ \\ ${ }^{1}$ Department of Chemistry, University of York, Heslington, UK \\ ${ }^{2}$ School of Earth, Atmospheric and Environmental Science, The University of Manchester, Simon Building, Oxford Road, \\ Manchester, UK
}

Received: 9 March 2009 - Published in Atmos. Meas. Tech. Discuss.: 30 March 2009

Revised: 13 July 2009 - Accepted: 20 July 2009 - Published: 7 August 2009

\begin{abstract}
Very short lived halocarbons (VSLH) play an important role in the transport of halogen atoms to the troposphere and lower stratosphere. Here we describe the development of a relaxed eddy accumulation system using gas chromatography coupled to a mass spectrometer (REA-GC/MS) to determine surface fluxes of VSLH with a time resolution of about $0.5 \mathrm{~h}$. Laboratory tests showed that use of a common inlet for upward, downward and deadband flow paths resulted in mixing of upward and downward moving air masses, therefore we recommend the use of separate inlets. The modified system underwent field trials at Mace Head on the west coast of Ireland, where there are dense kelp beds known to emit a range of halocarbons. Over a $16 \mathrm{~h}$ period in mid-September 2007, the mean fluxes obtained were $16.1 \pm 1.8,4.0 \pm 0.54$ and $1.2 \pm 0.2 \mathrm{nmol} \mathrm{m}^{-2} \mathrm{day}^{-1}$ for $\mathrm{CH}_{2} \mathrm{Br}_{2}, \mathrm{CH}_{2} \mathrm{ICl}$ and $\mathrm{CH}_{2} \mathrm{IBr}$, respectively.
\end{abstract}

\section{Introduction}

Volatile organic halogens are ubiquitously observed in marine environments (Carpenter et al., 1999; Abrahamsson et al., 2004; Chuck et al., 2005; Butler et al., 2007). They are thought to be produced mainly by micro and macroalgae (Ekdahl et al., 1998; Carpenter et al., 1999; Laturnus, 2001; Dembitsky, 2006) in seawater. VSLH, comprising bromine and/or iodine-containing hydrocarbons, photolyse in the troposphere or lower stratosphere to give halogen atoms which, via a variety of catalytic pathways, deplete sur-

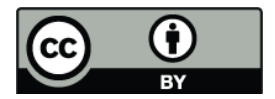

Correspondence to: K. E. Hornsby (keh114@york.ac.uk) face ozone concentrations and perturb free radical populations (von Glasow et al., 2004; Yang et al., 2005). Iodine oxide radicals produced as a result of these interactions potentially produce new aerosol particles and result in the formation of cloud condensation nuclei (O'Dowd et al., 2002; McFiggans et al., 2004), which in turn affects climate.

The data available on the distributions and concentrations in air and in seawater of VSLHs are rather limited (Atlas et al., 1993; Connan et al., 1996; Yamamoto et al., 2001; Carpenter et al., 2007). Determination of sea-air fluxes from simultaneous air and water measurements are even more limited and subject to significant spatial and temporal uncertainty (Baker et al., 2000; Chuck et al., 2005; Butler et al., 2007; Zhou et al., 2008). Sea-air fluxes of trace gases are calculated from such measurements using Eq. (1),

$F=k_{w}\left(C_{w}-\frac{C_{a}}{H}\right)$

where $C_{w}$ and $C_{a}$ are the concentrations in surface sea water and in air, respectively, $H$ is the dimensionless Henry's law coefficient and $k_{w}$ is the gas transfer velocity (Liss and Merlivat, 1986) which in turn is usually calculated from an empirical equation dependant on wind speed. In order to calculate the transfer velocity, the Schmitt number for the species is required. For some halocarbons there are no measurements of this parameter, therefore an approximation can be made using the Schmitt number of $\mathrm{CO}_{2}$ (Wanninkhof, 1992; Nightingale et al., 2000). Shown in Eq. (2) is the Nightingale parameritisation for $k_{w}$,

$$
k_{w}=\left(0.222 u^{2}+0.333 u\right)\left(\frac{S c}{660}\right)^{-1 / 2}
$$


Where $u$ is the wind speed in $\mathrm{ms}^{-1}$ and $S c$ is the Schmitt number of the gas in question.

Whilst Eq. (1) allows calculation of sea-air fluxes for trace gases which are relatively well dispersed in the oceanic mixed layer, the difficulty in measuring true surface water concentrations can lead to errors in flux calculations, particularly for compounds which exhibit strong near surface gradients in seawater, such as the dihalomethanes $\mathrm{CH}_{2} \mathrm{I}_{2}$ and $\mathrm{CH}_{2} \mathrm{ICl}$ (Jones and Carpenter, 2006; Martino et al., 2006). Furthermore, determination of fluxes over exposed seaweed beds is not possible with this technique, despite the fact that these are known to produce large quantities of VSLHs (Nightingale et al., 1995; Ekdahl et al., 1998; Baker et al., 2001). Consequently, a reliable method for coastal quantification and direct measurement of halocarbon fluxes in the marine environment is required.

Relaxed Eddy Accumulation (REA) is a conditional sampling technique which has been developed as a relaxation of the Eddy Accumulation (EA) approach suggested by Desjardins (1974) and is related to the widely used eddy covariance technique (EC), e.g. Foken (2008), Pryor et al. (2007). EC uses a fast response sensor to make real-time concentration measurements of the target compound and uses data from a sonic anemometer and air sampled at a rate proportional to the vertical wind speed to calculate the flux. However due to the challenges in using eddy covariance for determining fluxes for a variety of trace gas species, work has focused on the application of REA. REA is a derivative of EA that was first proposed by Hicks and McMillen (1984) and formulated in detail by Businger and Oncley (1990). REA can therefore be used to measure trace atmospheric gases for which fast response sensors $(>10 \mathrm{~Hz})$ required for EC are not available (Businger and Oncley, 1990). In REA, upward moving air (from the surface) and downward moving air (bulk air considered to be well mixed) created from eddies in the air column, are separated into reservoirs and fluxes are calculated using Eq. (3),

$F=\beta \sigma_{w} \Delta C$

where $\Delta \mathrm{C}$ is the difference in mean concentration of the upward and downward moving eddies, $\sigma_{w}$ the standard deviation of the mean vertical wind velocity and $\beta$ an empirical coefficient (Businger and Oncley, 1990) calculated from insitu eddy correlation measurements of the sensible heat flux using Eq. (4) (Zemmelink et al., 2004),

$\beta=\frac{\overline{w^{\prime} \theta^{\prime}}}{\sigma_{w}\left(\overline{\theta_{u}}-\overline{\theta_{d}}\right)}$

where $\theta_{u}$ and $\theta_{d}$ are the average temperatures in the upward and downward wind directions and $\overline{w^{\prime} \theta^{\prime}}$ is the sensible heat flux. Values of $\beta$ are typically around 0.56 and are weakly dependant on the stability of the wind regiment at the time of the measurement. The benefit of REA is that the separated upward and downward moving air masses can be stored then analysed using relatively slow methods such as gas chromatography coupled with mass spectrometry at a later date. REA has been successfully developed and validated by means of $\mathrm{EC}$ for measurements of fluxes of $\mathrm{CO}_{2}$ (Pattey et al., 1993), volatile organic compounds (VOCs) such as isoprene and monoterpenes (Bowling et al., 1998; Lee et al., 2005) and aerosols (Schery et al., 1998; Gaman et al., 2004; Grönholm et al., 2007), however it is still technically challenging. Uncertainties in fluxes derived by the REA technique are discussed by Pattey et al., (1993) and Kramm et al., (1999).

Here we describe the development and initial field trials of an REA-GC/MS system for the measurement of halocarbon fluxes.

\section{Methods}

\subsection{REA system}

The initial design for the REA system consisted of a common inlet split into three flow paths: up and down sampling reservoirs and a "dead band". This common inlet design, as used by Bowling et al. (1998), was chosen to ensure that the air mass sampled was the one measured by the sonic anemometer. The up and down sampling reservoirs consist of thermal desorption tubes, 5 stainless steel pre-packed tubes filled with 3 different carbon based adsorbents (Carbopack B, Carbopack C and Carboseive III, Supelco, UK. Supplied by Marks International, UK) packed in increasing order of strength. The tubes were arranged to allow continuous sampling by connecting them to a 16-port Vici trapping/flowthrough multi-position valve with a common inlet and a common outlet, allowing each tube to be isolated from the atmosphere until required for sampling. The dead band flow path was used to prevent sampling during rapid changes in the vertical wind speed and distortion of the observed fluxes (Zemmelink et al., 2004) by removing air moving at wind speeds of $\leq \pm 0.05 \mathrm{~ms}^{-1}$. The deadband flow limit could be manually increased or decreased within the control program depending on the likely size of the eddies to be observed. All three flow paths through the system were of equal length and flow restriction to reduce fluctuations in flow rate as a result of switching. All flow paths were bracketed by a pair of fast switching valves (Sirai, Italy) to isolate the reservoirs while not required for sampling. Air samples were dried prior to trapping on the tubes by a Nafion ${ }^{\mathrm{TM}}$ membrane (Brunswick Instruments, USA) molecular sieve dryer. Flows through the system were monitored by a mass flow meter (Alicat) and controlled using a Venturi handled needle valve (Swagelok, USA) acting as a critical orifice (Fig. 1a). Usually, REA flux measurements must be corrected for the influence of water vapour and volumetric flow rate (Pattey et al., 1992), however in this system there is no need for such corrections because of the use of a Nafion/molecular sieve drier which 
Table 1. Quantification ions, uncertainty in online air and REA measurements, precision for online air and REA measurements and concentration of in house standard.

\begin{tabular}{|c|c|c|c|c|c|c|}
\hline Compound & $\begin{array}{l}\text { Identification and } \\
\text { quantificationions } / \mathrm{m} / \mathrm{z}\end{array}$ & $\begin{array}{c}\text { Uncertainty in online } \\
\text { air measurements/\%S.D. } \pm\end{array}$ & $\begin{array}{l}\text { Uncertainty in REA } \\
\text { measurements/\%S.D. } \pm\end{array}$ & $\begin{array}{c}\text { Precision of online } \\
\text { air measurements/\%S.D. } \pm\end{array}$ & $\begin{array}{c}\text { Precision of REAmeasurements/ } \\
\text { \%S.D. } \pm\end{array}$ & $\begin{array}{c}\text { Standard concentration/ } \\
\text { pptv }\end{array}$ \\
\hline $\mathrm{CH}_{2} \mathrm{Br}_{2}$ & 174,176 & 3.1 & 4.2 & 11.2 & 11.4 & $19.2 \pm 1.6$ \\
\hline $\mathrm{CH}_{2} \mathrm{ICl}$ & 127,176 & 2.5 & 8.9 & 11.0 & 13.8 & $15.5 \pm 1.2$ \\
\hline $\mathrm{CH}_{2} \mathrm{IBr}$ & 220,222 & 6.0 & 6.4 & 12.4 & 12.5 & $36.0 \pm 4.5$ \\
\hline
\end{tabular}

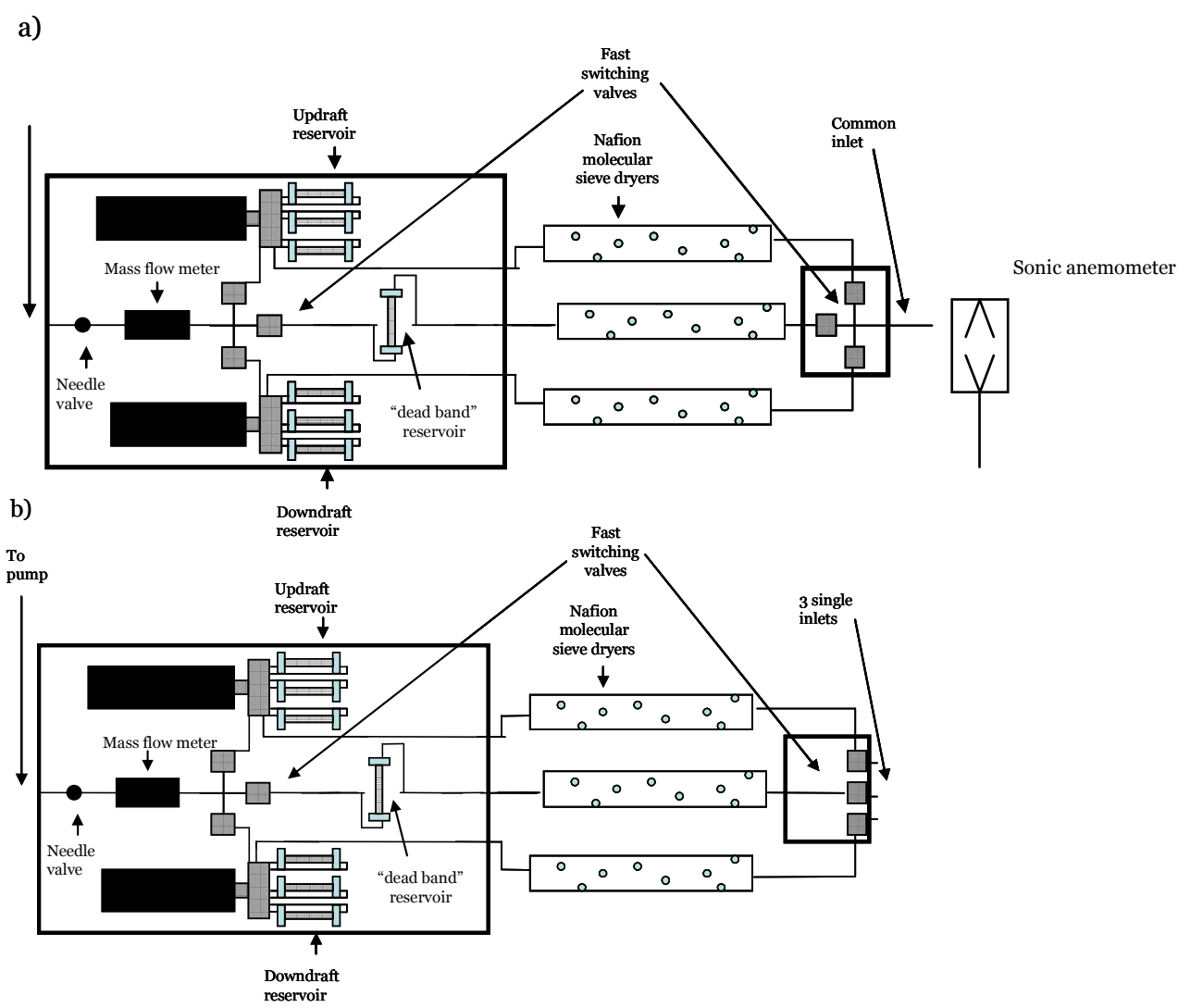

Fig. 1. (a) Initial REA system as trialled in the REA simulations, showing the position of the common inlet relative to the sonic anemometer. The inlet leads to the first set of fast switching valves followed by Nafion ${ }^{\mathrm{TM}}$ molecular sieve dryers before the air enters the relevant reservoir. The air is stripped of the halocarbons then exists the system via a mass flow meter and needle valve, acting as a critical orifice, to the pump which is situated down stream; (b) the modified REA system as deployed in the field trials, with three separate inlets, one for each flow path through the system.

reduced the dew point of the air sampled to a uniform $-26^{\circ} \mathrm{C}$ and mass flow meter which monitors fluctuations in air temperature in real time, meaning that fluctuations in humidity and pressure are already accounted for.

The fast switching valves were controlled from a sonic anemometer (Gill UK, Model R3) with the sonic transducer assembly mounted in the vertical. The minimum response time of the sonic anemometer was $0.020 \mathrm{~s}$ and the sonic transducer pathlength was $15 \mathrm{~cm}$. The serial output data from the sonic anemometer was coupled to a computer running data acquisition software written in LAB View 8. The fast switch valves had a response time of $0.1 \mathrm{~s}$ so the data from the sonic anemometer were averaged and recorded at the same rate. The fast response time was required to prevent lag within the system which would create mixing of the air masses and distort the results. The electronics and switching valves were mounted in a small box $(9 \times 12 \times 20 \mathrm{~cm})$ downstream of the sonic anemometer (which is $70 \mathrm{~cm}$ tall) with the air inlet co-located with the sonic anemometer sample volume to ensure concurrent vertical velocity and air mass concentration measurement. The 16-port valves, flow meters and adsorbent tubes were placed in a second housing, $150 \mathrm{~cm}$ 
further downwind of the switching valve housing and sonic anemometer, to further minimise flow distortion at the sonic anemometer.

The sonic EC system also provided supporting measurements of latent heat flux using a Krypton Hygrometer (Campbell Scientific Ltd., response time $<0.02$ s) and temperature and relative humidity, as well as pressure (Vaisala Models HMP-100 and PTB-100, respectively).

\subsection{Tube and on-line air analysis by GC/MS}

Commercially available traps of three adsorbents supplied pre-packed in the thermal desorption tubes were used in this study. The strength of sorbent increases through the tube in the direction of flow, the more volatile compounds are trapped on the stronger sorbent. These have been shown to be capable of trapping volatile organic compounds from large volumes of $\sim 3-4 \mathrm{~L}$ without breakthrough (Watson, 2008). The average volume of air trapped on the tubes for the REA analyses was $3 \mathrm{~L}$.

The tube samples were analysed using a Perkin Elmer (USA) Turbomass GC/MS system connected to a Perkin Elmer Automated Thermal Desorption unit (ATD). Each tube was desorbed for $30 \mathrm{~min}$ at a flow rate of $30 \mathrm{ml} \mathrm{min}^{-1}$ and a temperature of $300^{\circ} \mathrm{C}$ onto the cold microtrap of the ATD, consisting of a 3-stage carbon-based adsorbent (Air monitoring trap, Perkin Elmer UK) maintained at $-30^{\circ} \mathrm{C}$. The cold microtrap was then flash heated to $360^{\circ} \mathrm{C}$ and injected onto a $60 \mathrm{~m}$ DB5 GC column (Supelco). The oven program started at $35^{\circ} \mathrm{C}$ and was held for 9 mins before ramping up to $180^{\circ} \mathrm{C}$ at a rate of $10^{\circ} \mathrm{C} \mathrm{min}^{-1}$, holding for $1 \mathrm{~min}$ and finally ramping to $200^{\circ} \mathrm{C}$ at a rate of $25^{\circ} \mathrm{C} \mathrm{min}^{-1}$. The oven was held at $200^{\circ} \mathrm{C}$ for $15 \mathrm{~min}$ before cooling. The MS was run in selective ion recording (SIR) mode with a dwell time of $0.15 \mathrm{~s}$ on each of the two ions used for identification and quantifications (Table 1).

Online air measurements were made by trapping air dried by passage through a Nafion ${ }^{\mathrm{TM}}$ membrane (Brunswick Instruments, USA) molecular sieve dryer directly onto the cold trap of the ATD before analysis using the same oven program and MS conditions as the tube samples. The online air samples were trapped at $100 \mathrm{ml} \mathrm{min}^{-1}$ for 30 mins at $-30^{\circ} \mathrm{C}$ every 45 mins during the REA sampling period.

\subsection{Calibration and system performance}

The GC/MS was calibrated using a two stage process. A gas standard containing low-pptv mixing ratios of the target halocarbons (Table 1) was prepared. This gas standard was used in the field to calibrate the GC/MS and was quantified in our laboratory against an in-house built permeation system (Wevill and Carpenter, 2004) immediately after the campaign. The standard was prepared by injecting $\mu \mathrm{mol}$ amounts of the pure compound into $70 \mathrm{ml}$ HPLC grade methanol (Fisher UK), without head space. $4 \mu 1$ of this solution was injected into 1.11 of HPLC water (Fisher UK) without head space. $20 \mathrm{ml}$ of the resulting solution was purged at a temperature of $90^{\circ} \mathrm{C}$ with zero grade nitrogen (BOC UK) and collected in an evacuated, cleaned Aculife cylinder (10 L, CK Gases). The resulting gas standard was diluted by a factor of 300 with zero grade nitrogen (BOC UK). The permeation system used to calibrate the standard consists of permeation tubes (EcoScientific) filled with pure liquids (Sigma Aldrich) placed inside one of two gas-tight glass ovens mounted in aluminium heating blocks held at 40 and $70^{\circ} \mathrm{C}$ with a constant flow of nitrogen at $100 \mathrm{ml} \mathrm{min}^{-1}$. The halocarbon permeation tubes were positioned in the two ovens based on the halocarbon volatility, with the less volatile species placed in the hotter oven. Slugs of permeation gas were injected into a stream of nitrogen gas by means of a two flow path Vici valve connected to a $10 \mu \mathrm{l}$ sample loop (Restek UK), allowing specific volumes of the permeation gas to be introduced.

The errors of the online air and tube analyses were estimated using a Gaussian propagation of errors and are shown in Table 1. The error includes the uncertainty on the slope of the calibration curve, the uncertainty of the permeation tube weightings and the precision of the online air/tube measurement made using the GC/MS. Precisions for the tubes were determined by analysis of 5 consecutive tubes loaded with halocarbon standard (Table 1) and 5 consecutive online standards for the online air. The error on the flux measurements is discussed in Sect. 3.

Breakthrough volumes were assessed in the field using three pairs of tubes loaded concurrently with ambient air. The flow rates were set such that 3,4 , and $5 \mathrm{~L}$ were trapped in the same $20 \mathrm{~min}$ sampling period. The GC/MS analysis showed that these volumes were below the breakthrough volume of the tubes.

\subsection{Footprint calculations}

Footprints were calculated using measured wind velocities, friction velocity and sensible heat flux from the sonic anemometer at the site as input to the 3 dimensional analytical approximation of Schmid (1994).

The roughness length, $z_{0}$, for terrestrial surfaces used in this model can be calculated using the following equation,

$z_{0}=\frac{z_{m}-d}{\exp \left(\frac{k U}{u_{*} \Phi_{m}}\right)}$

where $z_{m}$ is the measurement height, $d$ is the zero plane displacement, $k$ is the von Karman constant $(\sim 0.41$, empiricamlly determined), $U$ is the wind speed, $u_{*}$ is the friction velocity and $\Phi_{m}$ is the stability parameter. For water surfaces which may influence some observations at coastal zones in 
the transition from low to high tide, $z_{0}$ can be determined using the relationship described by e.g. Zilitinkevich (1969)

$z_{0}=c_{1} \frac{v}{u_{*}}+\frac{u_{*}^{2}}{c_{2} g}$

where $\mathrm{c}_{1}$ and $\mathrm{c}_{2}$ are coefficients with highly variable values, $\mathrm{c}_{1} \sim 0.0-0.48$, and $\mathrm{c}_{2}$ ranges from $\infty$ to 81.1 (the commonly used Charnock (1955) relationship employs $c_{1}=0.0$ and $\mathrm{c}_{2}=81.1$ although this may underestimate $z_{0}$ for open/rough seas), $u_{*}$ is the friction speed, $g$ the acceleration due to gravity and $v$ is the kinematic viscosity.

\section{Results and discussion}

\subsection{Laboratory testing of REA GC/MS}

The REA GC/MS system underwent two testing phases to ensure that complete separation of the upward and downward moving air masses could be achieved, which is essential for quantitative calculation of fluxes. The test rig for these experiments consisted of two additional pairs of fast switching valves, set such that there was no build up of pressure in the system. One pair of gas valves was synchronised with the updraft valve and the other with the downward draft valve. The standard was connected to the updraft switching valves and used to supply the system with "updraft" air. Connected to the other pair of switching valves was clean $\mathrm{N}_{2}$ to supply "downdraft" air.

For the first test, the system switched between the updraft and downdraft reservoirs at regulated frequencies of 10,5 and $1 \mathrm{~Hz}$. A flow rate of $300 \mathrm{ml} \mathrm{min}^{-1}$ was used and the percentage of "updraft" air present on the updraft tube of the pair was calculated by summing the peak areas on both tubes and calculating the percentage present on the updraft tube, and was used to gauge how much mixing had occurred between the two flow paths. The second test used data recorded by the sonic anemometer from a field experiment at a coastal site in northern France. This "real world" turbulence file was used as a reference to simulate switching frequencies and to control switching between the updraft and downdraft reservoirs with a variable deadband. Two simulations were conducted. In simulation A, the deadband flow limit was $0.05 \mathrm{~m} \mathrm{~s}^{-1}$ and in simulation B the dead band flow limit was increased to $\pm 0.1 \mathrm{~m} \mathrm{~s}^{-1}$. The purpose of these simulations was to assess any change in the amount of mixing that occurred when the switching became irregular and the extent to which the deadband was able to recover the resolution of the two reference air masses.

Shown in Fig. 2 are the results for 3 representative halocarbons $\left(\mathrm{CH}_{2} \mathrm{Br}_{2}, \mathrm{CH}_{2} \mathrm{ICl}\right.$ and $\left.\mathrm{CH}_{2} \mathrm{IBr}\right)$ for the five test scenarios. For $\mathrm{CH}_{2} \mathrm{Br}_{2}$, the percentage of updraft air in the updraft tube increased as the switching rate decreased. This was as expected because slower switching rates mean longer periods of uninterrupted air. However, for some compounds

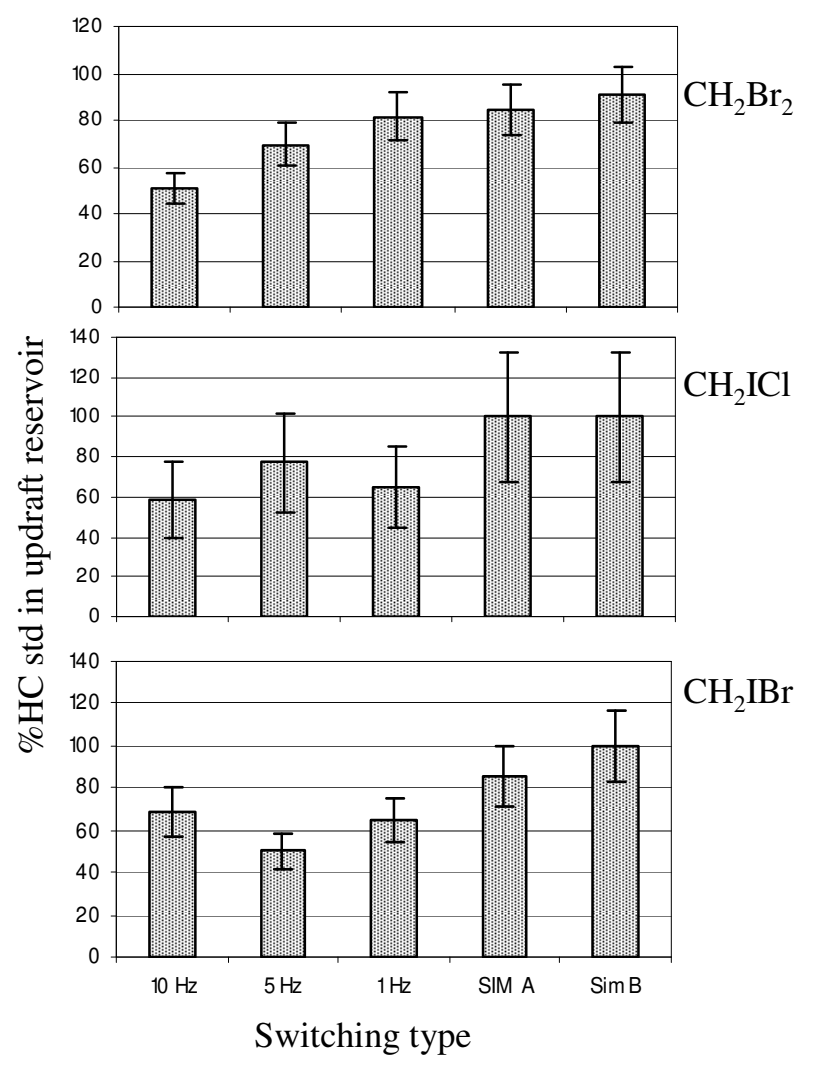

Fig. 2. Results from the simulation tests carried out on the initial REA system. The tests shown are for regulated switching at 10 , 5 and $1 \mathrm{~Hz}$. Two simulations, A and B, used dead-band values of 0.05 and $0.1 \mathrm{~m} \mathrm{~s}^{-1}$. The results show improvement in separation for $\mathrm{CH}_{2} \mathrm{Br}_{2}$ as the switching rate decreases and the dead band increases and variations for $\mathrm{CH}_{2} \mathrm{ICl}$ and $\mathrm{CH}_{2} \mathrm{IBr}$ as the switching rate decreases but improvement with the introduction of the dead-band to the "real world" sonic turbulence file runs. The error bars indicate the precision of the measurement made using the adsorbent tubes.

like $\mathrm{CH}_{2} \mathrm{ICl}$, there was no discernable increase in the discrimination as the switching frequency decreased, although improvement occurred with the introduction of the deadband during real sonic file tests. The simulations also showed that the larger the deadband, the more efficiently the compounds were separated. However, the effect of increasing the deadband flow limit from $0.0 \mathrm{~ms}^{-1}$ to $0.1 \mathrm{~ms}^{-1}$ was that in the 20 min sampling period, the volume trapped on the individual tubes was reduced from $2.5 \mathrm{~L}$ to just under $2 \mathrm{~L}$, i.e. the sensitivity of the measurement for a particular time period was reduced. Although the difference in concentration between the up and down draft would increase the absolute concentration in the sample would decrease meaning both concentrations would be below the limit of detection. In order to both prevent mixing of up and down-draft air and maintain a relatively small deadband flow rate, the REA system was modified so that each flow path had an individual inlet to prevent mixing (Fig. 1b). 
Table 2. Ratio of day to night fluxes comparing periods with the same tidal signature.

\begin{tabular}{cccccc}
\hline Compound & $11: 25,10 / 09 / 07 /$ & $12: 00,10 / 09 / 07 /$ & $12: 35,10 / 09 / 07 /$ & $13: 10,10 / 09 / 07 /$ & Average \\
& $00: 15,11 / 09 / 07$ & $00: 50,11 / 09 / 07$ & $01: 25,11 / 09 / 07$ & $02: 00,11 / 09 / 07$ & \\
\hline $\mathrm{CH}_{2} \mathrm{Br} 2$ & 1.3 & 2.9 & 6.8 & 3.0 & 3.5 \\
$\mathrm{CH}_{2} \mathrm{ICl}$ & 0.6 & 3.1 & 1.8 & 1.3 & 1.7 \\
$\mathrm{CH}_{2} \mathrm{IBr}$ & 2.1 & 2.0 & 4.5 & 0.3 & 2.2 \\
\hline
\end{tabular}

\subsection{Reproducibility and sensitivity}

Because of the highly photolabile nature of some of the target halocarbons, it is expected that the concentrations in many of the tubes (particularly downdraft tubes) would be lower than the limit of detection (LOD). Discarding this data would lead to low data coverage. For samples where a tube was under the detection limit, fluxes were calculated using (i) the measured value, (ii) the LOD and (iii) half the LOD, in place of the measured value. In this way it is possible to estimate an upper and lower limit for the calculated fluxes. In practice, the variability introduced into the fluxes by taking this approach was less than the calculated precision of the flux results. In REA, the concentration observed in the downdraft is subtracted from the concentration in the updraft. Consequently, the precision of an REA measurement is the Gaussian propagated precision for the analyses of two tubes (Sect. 2.3 and Table 1, also see Kramm et al., 1999). A limit of calculable flux (LOCF) is calculated from the product of the percentage precision (Table 1) and the highest concentration in the tube pair. The LOCF represents the smallest $\Delta \mathrm{C}$ (positive or negative) that can be calculated given the precision of the individual updraft and downdraft concentration measurements; a particular flux measurement will be above the LOCF if $\triangle \mathrm{C}$ is greater than this quantity. The LOCF is expressed as a flux using Eq. (3).

\subsection{Summary of results from BIOFLUX II campaign}

The REA system was first deployed as part of an INTROP exchange trip, the Biogenic Flux Experiment phase II (BIOFLUX II), which took place at the Atmospheric Research Station at Mace Head on the West Coast of Ireland (53 $13^{\prime} 33 \mathrm{~N}, 9^{\circ} 54^{\prime} 00 \mathrm{~W}$ ) (Simmonds and Derwent, 1991), between the 20th of August and the 15th of September 2007. Mace Head was selected for the initial trial of the new flux measuring technique because high fluxes were expected given the well documented halocarbon concentrations at this site (Carpenter et al., 1999 and 2000). Detailed consideration of the spatial location of sources was considered beyond the scope of this trial deployment, but would be important in future work using the REA system to assess the impact of different macroalgae to halocarbon fluxes.

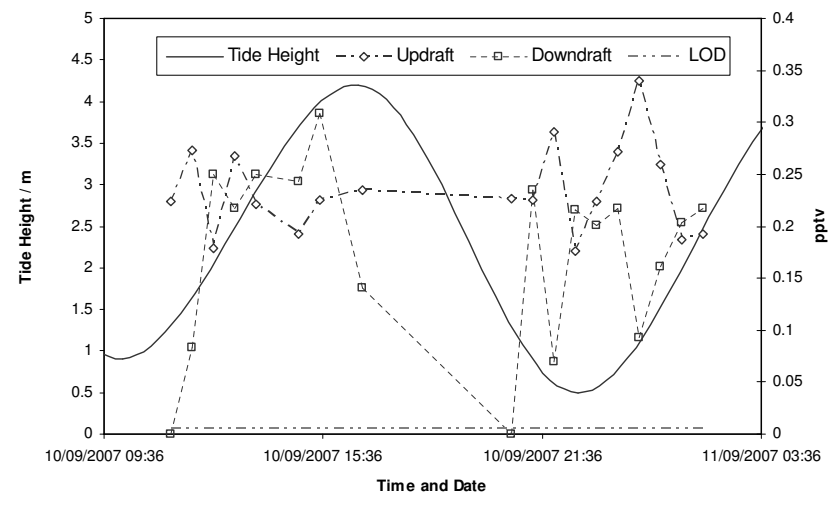

Fig. 3. Updraft concentrations(black dashed line with white diamonds) and downdraft concentrations (black dashed line with white squares) of $\mathrm{CH}_{2} \mathrm{Br}_{2}$ plotted with tide height (black solid line) and limit of detection (grey dashed line)

The REA system was sited at a height of $8 \mathrm{~m}$ on the preexisting $23 \mathrm{~m}$ tower at the site (Heard et al., 2006). For a uniform and horizontal surface, $\bar{w}=0$, resulting in negligible vertical transport. This was the assumption made for the sampling period. However, the terrain at Mace Head slopes down towards the sea and comprises of a mixture of boulders and grass. This creates a bias in the mean vertical wind speed. Bowling et al. (1998) found that correcting for bias in $\sigma w$ by applying digital filters to the sonic data before sampling had very little effect on the measured flux although they did conclude that further investigation was required. Consequently, no adjustment was made to account for potential bias at the point of sampling in this investigation.

The samples were taken in 5 hourly batches, with each REA collection period lasting $35 \mathrm{~min}$, and analysed within $24 \mathrm{~h}$ of collection. Shown in Fig. 3 are the concentrations observed in the updraft and the downdraft air for $\mathrm{CH}_{2} \mathrm{Br}_{2}$ for the 10th to the 11th of September along with the limit of detection and tidal height. There was a much larger level of variation in the downdraft compared to the updraft $\mathrm{CH}_{2} \mathrm{Br}_{2}$ concentrations. The increases observed in the downdraft occured after an increase in the updraft concentrations, but do not appear to be closely related to tide height. Shown in Table 2 are the range and mean fluxes of all the species observed and in Fig. 4 are a time series of three representative 


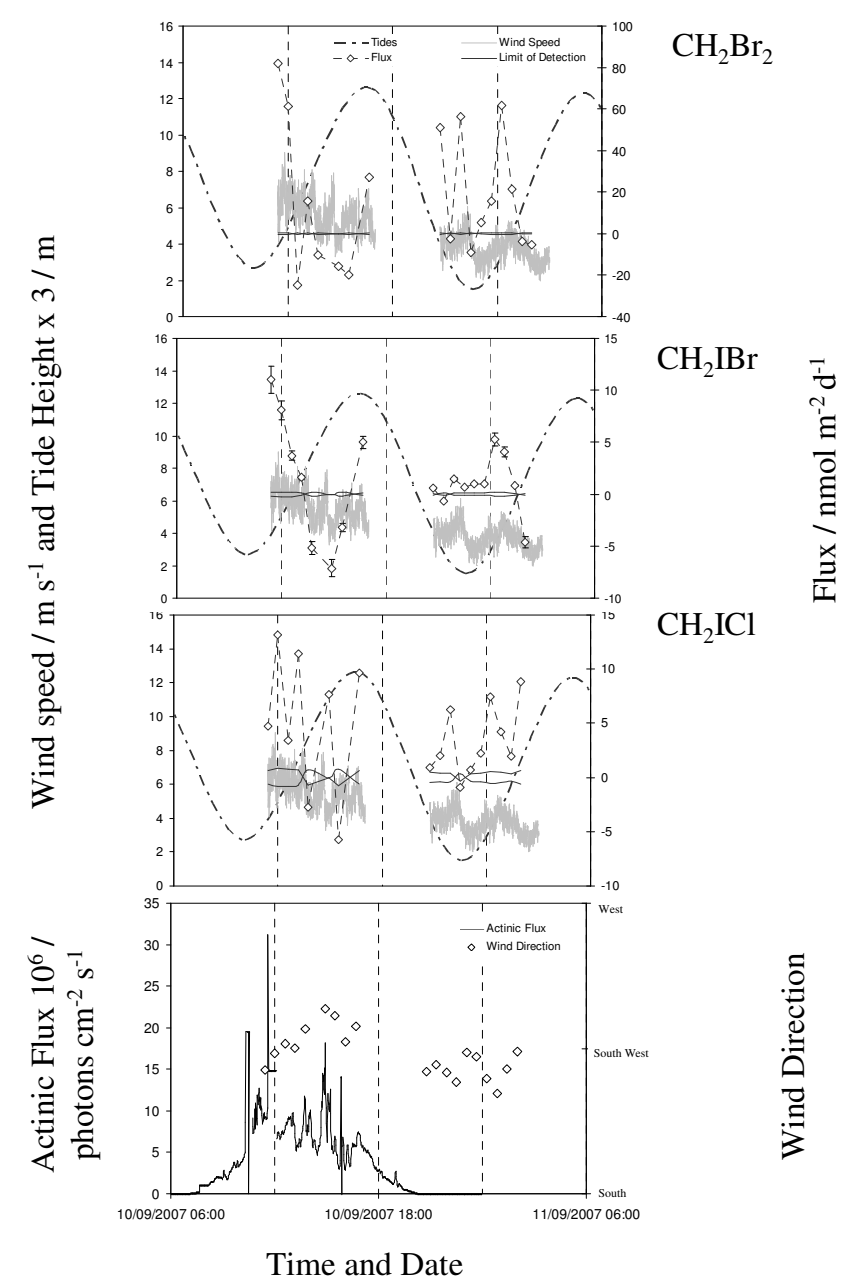

Fig. 4. Initial field results from the BIOFLUX II campaign showing: wind speed (grey solid line), tide height (dark dashed line), the measured fluxes for $\mathrm{CH}_{2} \mathrm{Br}_{2}, \mathrm{CH}_{2} \mathrm{IBr}$ and $\mathrm{CH}_{2} \mathrm{ICl}$ in each panel respectively, are shown by the white diamonds; the solid black line shows positive and negative limit of calculable flux. Error bars show the $1 \sigma$ precision of the flux measurements. The bottom panel shows total downward actinic flux (black line) and average wind direction (white diamonds) for each sample period. Grey shading indicates hours of darkness.

halocarbon species along with the LOCF, wind speed and tidal height. All three halocarbon species exhibit higher fluxes during periods of low tide than those observed at high tide, $203 \% \pm 23 \%$ for $\mathrm{CH}_{2} \mathrm{Br}_{2}, 15 \% \pm 2.1 \%$ for $\mathrm{CH}_{2} \mathrm{ICl}$ and $120 \% \pm 15.0 \%$ for $\mathrm{CH}_{2} \mathrm{IBr}$, as expected given that seaweeds are the major source at this site (Carpenter et al., 2000). The wind direction during the REA sampling period was fairly constant (Fig. 4). In the first sample period the sample fetch remained between west and south west and during the second sample period between the south west and the south.

Dibromomethane showed a deposition during high tide and low wind speeds. This species is much longer lived $\left(\mathrm{CH}_{2} \mathrm{Br}_{2}\right.$ has a tropospheric lifetimes of 47 days, Mossinger et al., 1998) than the iodocarbons $\left(\mathrm{CH}_{2} \mathrm{ICl}\right.$ has lifetime of around 90 mins, Roehl et al., 1997, and $\mathrm{CH}_{2} \mathrm{IBr}$ around $45 \mathrm{~min}$ at midday, Mossinger et al., 1998) and may therefore be transported from surrounding oceanic/coastal regions to the site. Looking at the seaweed map in Fig. 5 it can be seen that there are large Laminaria beds containing both hyperborea and digitata about $2.5 \mathrm{~km}$ southwest of the site.

Deposition of bromocarbons has not previously been observed in coastal waters, in fact $\mathrm{CH}_{2} \mathrm{Br}_{2}$ is generally found to be supersaturated particularly in coastal waters (Butler et al., 2007). However, because Mace Head is surrounded by many seaweed-rich bays it is possible that air masses passing over exposed seaweed beds containing higher levels of $\mathrm{CH}_{2} \mathrm{Br}_{2}$ than the air in the immediate vicinity of the tower would present as downdraft air, causing an apparent deposition. The foot print of the REA system is further discussed in Sect. 3.4.

Macroalgae (seaweed) have been found to emit halocarbons more prolifically when under oxidative stress (e.g. sunlight) (Nightingale et al., 1995; Laturnus et al., 2004; Palmer et al., 2005). Further, rapid photolysis of the iodinecontaining photolabile halocarbons during daylight hours is expected to give rise to a strong concentration gradient from the surface, which potentially could give rise to a stronger upward flux at the surface. Although the data set is limited, by comparing periods with the same tidal signature, the day time fluxes were found to be an average of 2-3 times greater than during the night (Table 2). However, as discussed in Sect. 3.4, another factor affecting the fluxes is the wind speed and on the night of observations, the average day time wind speed $\left(5.6 \mathrm{~m} \mathrm{~s}^{-1}\right)$ was significantly higher than the average night time wind speed $\left(3.7 \mathrm{~m} \mathrm{~s}^{-1}\right)$.

Shown in Table 3 are the range and average measurements made for all the halocarbons observed. Also shown in Table 3 are the mean fluxes as measured by Greenberg et al. (2005) at Mace Head during September 2003 using the gradient flux technique. The gradient flux measurements quoted here are values as reported in Greenberg et al. averaged over 26 measurements made between the Mace Head research station and the Martin Ryan Institue round the bay. Given the different study periods and positions and inherent differences in techniques, our measurements are in reasonable agreement. The average $\mathrm{CH}_{2} \mathrm{Br}_{2}$ flux measured in this work was a factor of 2 lower than that measured by Greenberg et al. (2005) and the average $\mathrm{CH}_{2} \mathrm{IBr}$ fluxes are remarkably similar. It should be noted that the measurements of Greenberg et al. (2005) had a much larger foot print because the measurements were made at heights of 50 and $100 \mathrm{~m}$. This will affect the amount of mixing which occur in the air mass before sampling meaning that the resulant sampled air would be much more homogeneous than those observed by the REA system described in this paper. 
Table 3. Range and mean fluxes observed during the Bioflux II campaign and the fluxes obtained by Greenberg et al. (2005) at Mace Head using the Gradient flux method and averaged over seven samples.

\begin{tabular}{|c|c|c|c|}
\hline Compound & $\begin{array}{l}\text { Range } 10 \text { to } 90 \% / \\
\text { nmol m}^{-2} \text { day }^{-1}\end{array}$ & $\begin{array}{l}\text { Average flux/ } \\
\mathrm{nmol} \mathrm{m}^{-2} \mathrm{day}^{-1}\end{array}$ & $\begin{array}{l}\text { Greenberg et al. (2005) Average flux/ } \\
\text { nmol m-2 day }{ }^{-1}\end{array}$ \\
\hline $\mathrm{CH}_{2} \mathrm{Br}_{2}$ & $-16.5-63.3$ & 16.1 & 29.3 \\
\hline $\mathrm{CH}_{2} \mathrm{ICl}$ & $-1.2-11.6$ & 4.0 & \\
\hline $\mathrm{CH}_{2} \mathrm{IBr}$ & $-4.7-8.4$ & 1.2 & 1.1 \\
\hline
\end{tabular}
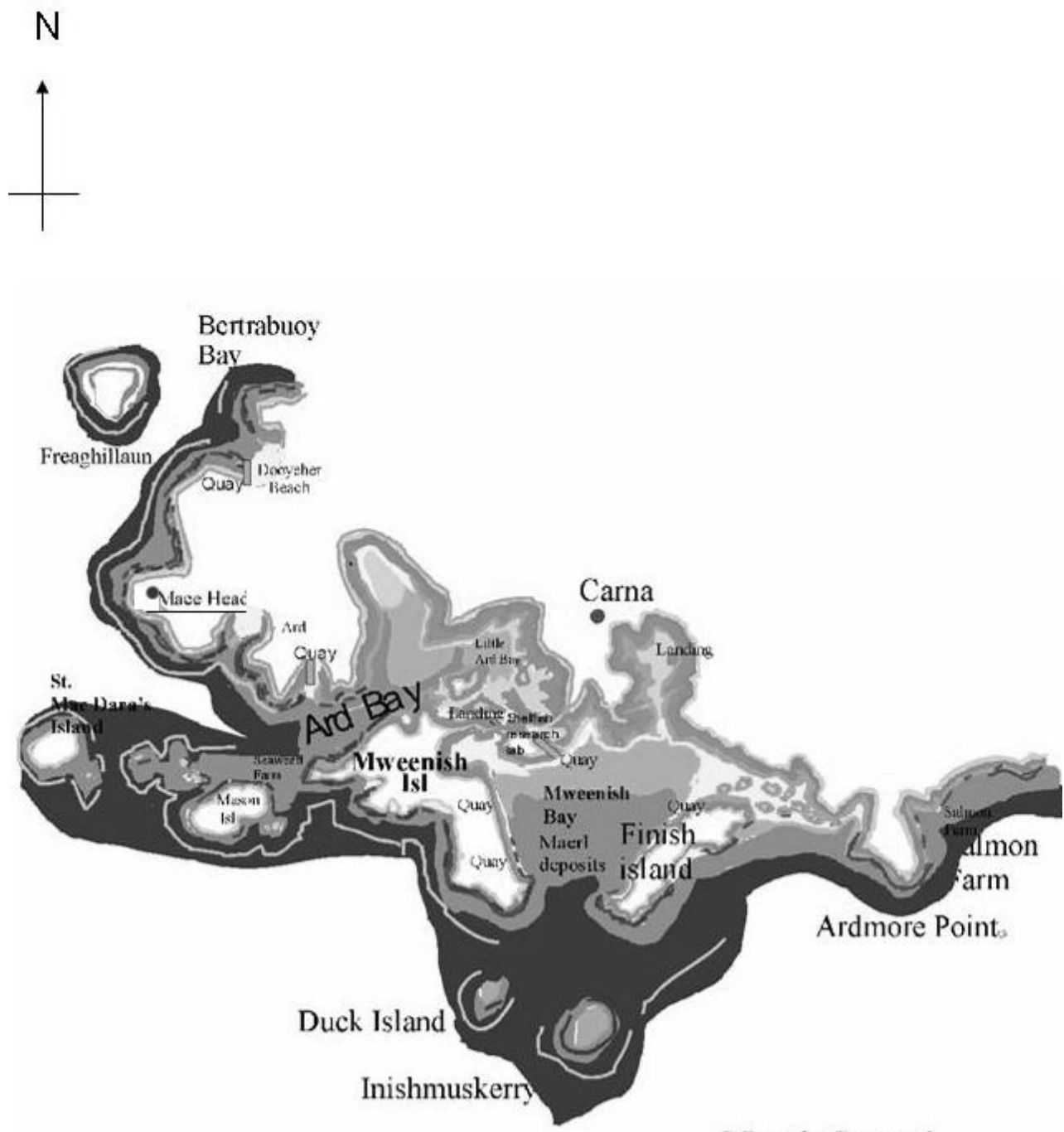

North Sound

Fig. 5. Seaweed map showing the three main species and their location around the Mace Head area. Laminaria digitata in solid grey, Laminaria hyperborea in dark grey and Alaria esculenta in white line. Taken from the Connemara Seaweed Survey, by the seaweed centre, National University of Ireland, Galway. 


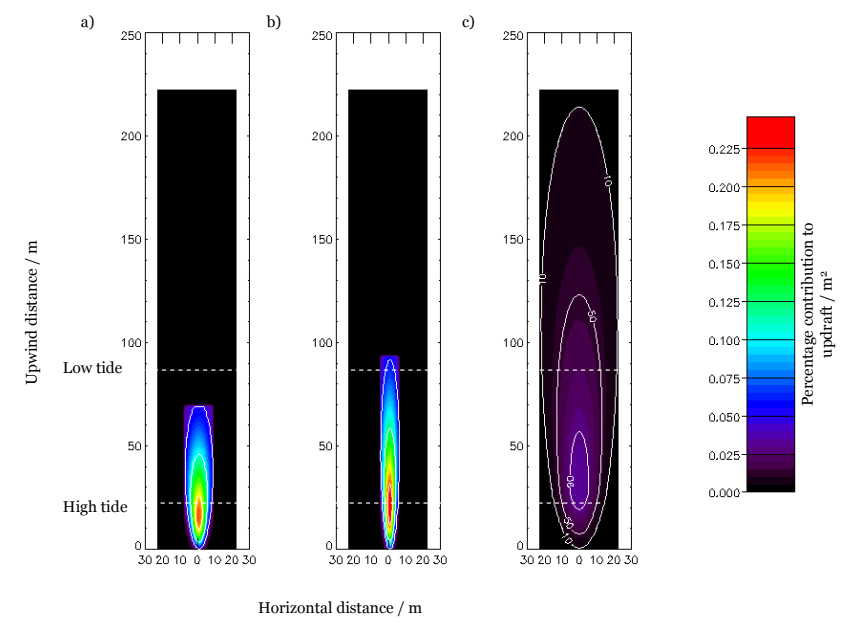

Fig. 6. Results of foot print modelling, (a) day time foot print at high tide, (b) night time foot print at low tide, (c) day time foot print at low tide. Tower location is at 0 on the horizontal axis. The white rings around the contours of the plot indicate the percentage contribution to the plot outside the ring. The white dotted lines indicate the position of high water and the approximate low water for the tidal period.

\subsection{Foot print calculations}

Having recorded differences in the fluxes between high and low tide as well as day and night, it is important to determine whether the variability is caused by changing surface conditions (exposure of seaweed at low tide) or by different meteorological conditions causing a change in the measurement footprint. Three tidal periods were chosen from the measurements including a high tide scenario during the day, and two low tide scenarios - one at night and one during the day where the measured fluxes were comparable. The three scenarios chosen for footprint modelling were high tide on the 10th of September at 15:30, low tide on the 11th of September at 00:15 and low tide on the 10th of September at 11:30 (shown in Fig. 6). The measurement height changes with the tide which in turn alters the roughness length. The footprint modelling shows that at low tide the fetch is larger than at high tide. This means that interpretation of the differences in high and low tide and day and night-time has to incorporate differences in the source footprint. Figure 6 shows that all the footprints have the greatest contribution to the updraft at roughly $25 \mathrm{~m}$ or more away from the base of the tower, which is approximately the location of the high water line during the period of investigation. As the tide recedes the foot print enlarges as the measurement height increases, giving a larger field of view. The waterline at low tide during this investigation was $\sim 75 \mathrm{~m}$ further away from the tower than the high tide waterline.

Direct comparison of the night- and day time low tide scenarios (Figure $6 \mathrm{~b}$ and $\mathrm{c}$ ) shows that when the wind speed

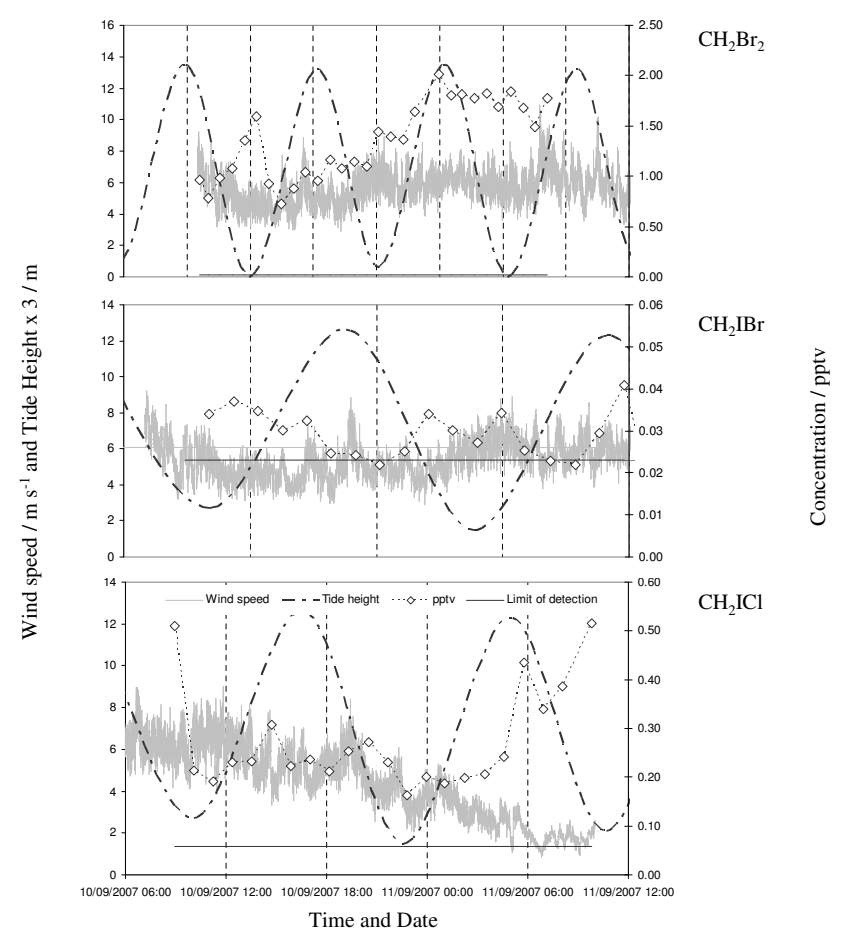

Fig. 7. Online air measurements co-located with the REA system. Tidal height, wind speed, limit of detection and concentration in pptv. Also shown are the precisions for the measurements as $1 \sigma$ error bars. Shaded areas indicate hours of darkness.

increases during the day, the catchment area (defined here as capturing $95 \%$ of emissions) is increased from $\sim 95 \mathrm{~m}$ to $\sim 225 \mathrm{~m}$. As discussed in Sect. 3.3 and shown in Table 2, daytime low tide fluxes were higher than nighttime low tide fluxes, by $32.7 \% \pm 3.7$ for $\mathrm{CH}_{2} \mathrm{Br}_{2}, 76.4 \% \pm 10.5$ for $\mathrm{CH}_{2} \mathrm{ICl}$ and $108 \% \pm 13.5$ for $\mathrm{CH}_{2} \mathrm{IBr}$. This could possibly be attributed to enhanced VSLH release from macroalgae during the day as a result of light induced oxidative stress. However, Figure 6 shows that another plausible explanation is that the daytime measurements captured more of the emissions from the lower littoral and upper sub-littoral zones where Laminaria are prevalent (Yonge, 1949; .Barnes, 1986). Laminaria species are among the most prolific emitters of VSLH, with measured release rates typically much larger than for other seaweeds such as Fucus that are found higher in the intertidal zonation (Nightingale et al., 1995). We conclude that the different footprints for the day and night mean that in our limited study, direct comparison of fluxes is not possible.

Whole air measurements were made simultaneously with the REA measurements. Shown in Fig. 7 are the online data with tidal height and wind speed. The halocarbons show a tidal signature with increases in concentration around low tide, particularly for $\mathrm{CH}_{2} \mathrm{ICl}$ which has a shorter lifetime than that of $\mathrm{CH}_{2} \mathrm{Br}_{2}$. These results are consistent with other measurements made at Mace Head during September (Carpenter et al., 2005). Assuming a vertical loss to the free troposphere 
of $350 \mathrm{~mol} \mathrm{air} \mathrm{m}^{-2} \mathrm{hr}^{-1}$.(WMO, 2003), a photolytic lifetime of 47 days for $\mathrm{CH}_{2} \mathrm{Br}_{2}$, and a boundary layer of $1 \mathrm{~km}$ we estimate that the average fluxes observed (Table 3) are capable of supplying approximately $\sim 6 \mathrm{pptv}$ of $\mathrm{CH}_{2} \mathrm{Br}_{2}$ to the MBL. Therefore, the atmospheric concentrations observed at the site have been diluted by background air containing significantly lower concentrations of $\mathrm{CH}_{2} \mathrm{Br}_{2}$.

\section{Summary}

A common inlet REA-GC/MS system has been developed and tested in a series of simulation tests to assess the mixing that occurs between updraft and downdraft air during sampling. Because these simulation tests showed that significant mixing occurred except at high deadband flow limits, the REA system was modified to incorporate separate inlets for each flow path (updraft, downdraft and deadband) through the system such that mixing of the air masses could not occur. The precision of the REA measurements were calculated by determining the reproducibility of the individual tube samples and propagating the error of the downdraft and updraft analyses, resulting in estimated errors of $11.4 \%, 13.8 \%$ and $12.5 \%$ respectively for $\mathrm{CH}_{2} \mathrm{Br}_{2}, \mathrm{CH}_{2} \mathrm{ICl}$ and $\mathrm{CH}_{2} \mathrm{IBr}$. The limits of calculable flux (LOCFs) calculated for the data obtained at Mace Head were well below the measured fluxes in most cases.

The system was field tested at Mace Head and flux measurements of 3 halocarbon species were made concurrently with whole air measurements. The fluxes showed similar patterns to the whole air measurements, with an increase at low tide. Whilst higher concentrations were observed during the night in whole air, presumably due to the fast photolysis of VSLH, lower fluxes were observed at night compared to the daytime by a factor of $2-3$. This could be due to a number of factors including a vertical concentration gradient in halocarbons during the day caused by their rapid photolysis, oxidative stress of macroalgae leading to higher daytime fluxes, or by the drop in wind speed during the night, causing a reduction in the sample catchment area. However, the limited data set prevents definitive conclusions from being drawn. Further investigation into the cause of the difference between daytime and nighttime fluxes is required.

The fluxes observed in this study were in good agreement with those of Greenberg et al. (2005), with $\mathrm{CH}_{2} \mathrm{Br}_{2}$ a factor of 2 lower and $\mathrm{CH}_{2} \mathrm{IBr}$ the same order of magnitude.

Acknowledgements. We acknowledge the European Science Foundation INTROP exchange scheme and the European Community EUSAAR Infrastructure fund, as well as NERC grant NE/D006538/1 for financial support. KEH acknowledges NERC for her studentship funding and R Leigh for assistance with data analysis.

Edited by: R. Koppmann

\section{References}

Abrahamsson, K., Loren, A., Wulff, A., and Wangberg, S. A.: Airsea exchange of halocarbons: The influence of diurnal and regional variations and distribution of pigments, Deep-Sea Res. Part II, 51, 2789-2805, doi:10.1016/j.dsr2.2004.09.005, 2004.

Atlas, E., Pollock, W., Greenberg, J., Heidt, L., and Thompson, A. M.: Alkyl nitrates, nonmethane hydrocarbons, and halocarbon gases over the equatorial Pacific-Ocean during SAGA-3, Journal of Geophysical Research-Atmospheres, 98, 16933-16947, 1993.

Baker, A. R., Turner, S. M., Broadgate, W. J., Thompson, A., McFiggans, G. B., Vesperini, O., Nightingale, P. D., Liss, P. S., and Jickells, T. D.: Distribution and sea-air fluxes of biogenic trace gases in the eastern Atlantic Ocean, Global Biogeochem. Cy., 14, 871-886, 2000.

Baker, J. M., Sturges, W. T., Sugier, J., Sunnenberg, G., Lovett, A. A., Reeves, C. E., Nightingale, P. D., and Penkett, S. A.: Emissions of $\mathrm{CH}_{3} \mathrm{Br}$, organochlorines, and organoiodines from temperate macroalgae, Chemosphere - Global Change Science, 3 , 93-106, 2001.

Barnes, B.: Coast and shore: A nature guide, The Crowood Press, Marlborough, UK, 32-40, 1986.

Bowling, D. R., Turnipseed, A. A., Delany, A. C., Baldocchi, D. D., Greenberg, J. P., and Monson, R. K.: The use of relaxed eddy accumulation to measure biosphere-atmosphere exchange of isoprene and other biological trace gases, Oecologia, 116, 306-315, 1998.

Brut, A., Legain, D., Durand, P., and Laville, P. A.: Relaxed Eddy Accumulator for Surface Flux Measurements on Ground-Based Platforms and Aboard Research Vessels, J. Atmos. Ocean. Technol., 21(3), 411-427, 2004.

Businger, J. A. and Oncley, S. P.: Flux measurement with conditional sampling, J. Atmos. Ocean. Technol., 7, 349-352, 1990.

Butler, J. H., King, D. B., Lobert, J. M., Montzka, S. A., YvonLewis, S. A., Hall, B. D., Warwick, N. J., Mondeel, D. J., Aydin, M., and Elkins, J. W.: Oceanic distributions and emissions of short-lived halocarbons, Global Biogeochem. Cy., 21, GB1023, doi:10.1029/2006GB002732, 2007.

Carpenter, L. J., Sturges, W. T., Penkett, S. A., Liss, P. S., Alicke, B., Hebestreit, K., and Platt, U.: Short-lived alkyl iodides and bromides at Mace Head, Ireland: Links to biogenic sources and halogen oxide production, J. Geophys. Res.-Atmos., 104, 16791689, 1999.

Carpenter, L. J., Malin, G., Kuepper, F., and Liss, P. S.: Novel biogenic iodine-containing trihalomethanes and other short-lived halocarbons in the coastal East Atlantic, Global Biogeochem. Cy., 14, 1191-1204, 2000.

Carpenter, L. J.,Wevil, D. J., Spain, G., and Simmonds, P. G.: Atmospheric bromoform at Mace Head, Ireland: Seasonality and evidence for a peatland source, Atmos. Chem. Phys., 5, 2927 2934, 2005

Carpenter, L. J., Wevill, D. J., Hopkins, J. R., Dunk, R. M., Jones, C. E., Hornsby, K. E., and McQuaid, J. B.: Bromoform in tropical Atlantic air from 25 degrees N to 25 degrees S, Geophys. Res. Lett., 34, L11810, doi:10.1029/2007GL029893, 2007.

Charnock, H.: Wind stress on a water surface, Q. J. R. Meteorol. Soc., 81, 639-640, 1955.

Chuck, A. L., Turner, S. M., and Liss, P. S.: Oceanic distributions and air-sea fluxes of biogenic halocarbons in the open ocean, J. Geophys. Res.-Ocean., 110, C10022, 
doi:10.1029/2004JL002741, 2005.

Connan, O., LeCorre, P., and Morin, P.: Purge and trap GC determination of volatile halocarbon compounds in seawater, Analusis, 24, 55-59, 1996.

Dembitsky, V. M.: Biogenic iodine and iodine-containing metabolites, Natural Product Communications, 1, 139-175, 2006.

Desjardins, R. 1.: Technique to measure $\mathrm{CO}_{2}$ exchange under field conditions, Int. J. Biometeorol., 18, 76-83, 1974.

Ekdahl, A., Pedersen, M., and Abrahamsson, K.: A study of the diurnal variation of biogenic volatile halocarbons, Mar. Chem., 63, 1-8, 1998.

Foken, T.: Micrometeorology, Pub. Springer Verlag, ISBN: 978-3540-74665-2, 308 pp., 2008.

Gaman, A., Rannik, Ü., Aalto, P., Pohja, T., Siivola, E., and coauthors: Relaxed eddy accumulation system for size resolved aerosol particle flux measurements, J. Atmos. Ocean. Technol. 21, 933-943, 2004.

Greenberg, J. P., Guenther, A. B., and Turnipseed, A.: Marine organic halide and isoprene emissions near Mace Head, Ireland, Environ. Chem., 2, 291-294, 2005.

Grönholm, T., Hiltunen, V., Aalto, P. P., Laakso, L., Rinne, J., and coauthors: Measurements of aerosol particle dry deposition velocities using relaxed eddy accumulation technique, Tellus 59, 381-386, 2007.

Heard, D. E., Read, K. A., Methven, J., Al-Haider, S., Bloss, W. J., Johnson, G. P., Pilling, M. J., Seakins, P. W., Smith, S. C., Sommariva, R., Stanton, J. C., Still, T. J., Ingham, T., Brooks, B., De Leeuw, G., Jackson, A. V., McQuaid, J. B., Morgan, R., Smith, M. H., Carpenter, L. J., Carslaw, N., Hamilton, J., Hopkins, J. R., Lee, J. D., Lewis, A. C., Purvis, R. M., Wevill, D. J., Brough, N., Green, T., Mills, G., Penkett, S. A., Plane, J. M. C., Saiz-Lopez, A., Worton, D., Monks, P. S., Fleming, Z., Rickard, A. R., Alfarra, M. R., Allan, J. D., Bower, K., Coe, H., Cubison, M., Flynn, M., McFiggans, G., Gallagher, M., Norton, E. G., O’Dowd, C. D., Shillito, J., Topping, D., Vaughan, G., Williams, P., Bitter, M., Ball, S. M., Jones, R. L., Povey, I. M., O’Doherty, S., Simmonds, P. G., Allen, A., Kinnersley, R. P., Beddows, D. C. S., Dall'Osto, M., Harrison, R. M., Donovan, R. J., Heal, M. R., Jennings, S. G., Noone, C., and Spain, G.: The north Atlantic marine boundary layer experiment (namblex). Overview of the campaign held at Mace Head, Ireland, in summer 2002, Atmos. Chem. Phys., 6, 2241-2272, 2006,

http://www.atmos-chem-phys.net/6/2241/2006/.

Hicks, B. B. and McMillen, R. T.: A simulation of the eddy accumulation method for measuring pollutant fluxes, J. Clim. Appl. Meteorol., 23, 637-643, 2004.

Jones, C. E., and Carpenter, L. J.: Solar photolysis of $\mathrm{CH}_{2} \mathrm{I}_{2}$, $\mathrm{CH}_{2} \mathrm{ICl}$, and $\mathrm{CH}_{2} \mathrm{IBr}$ in water, saltwater, and seawater, Environ. Sci. Technol., 40, 1372-1372, 2006.

Kramm, G., Beier, N., Dlugi, R., and Muller, H.: Evaluation of conditional sampling methods, Contribut. Atmos. Phys. 72, 161172. 1999.

Laturnus, F.: Marine macroalgae in polar regions as natural sources for volatile organohalogens, Environ. Sci. Poll. Res., 8, 103-108, 2001.

Laturnus, F., Svensson, T., Wiencke, C., and Oberg, G.: Ultraviolet radiation affects emission of ozone-depleting substances by marine macroalgae: Results from a laboratory incubation study, Environ. Sci. Technol., 38, 6605-6609, 2004.
Lee, A., Schade, G. W., Holzinger, R., and Goldstein, A. H.: A comparison of new measurements of total monoterpene flux with improved measurements of speciated monoterpene flux, Atmos. Chem. Phys., 5, 505-513, 2005,

http://www.atmos-chem-phys.net/5/505/2005/.

Liss, P. S. and Merlivat, L.: In the role of air-sea exchange in geochemical cycling, edited by: Buat-Menard, P., Reidel, Dordecht, The Netherlands, 113-127, 1986.

Martino, M., Liss, P. S., and Plane, J. M. C.: Wavelengthdependence of the photolysis of diiodomethane in seawater, Geophys. Res. Lett., 33, L06606, doi:10.1029/2005GL025424, 2006.

McFiggans, G., Coe, H., Burgess, R., Allan, J., Cubison, M., Alfarra, M. R., Saunders, R., Saiz-Lopez, A., Plane, J. M. C., Wevill, D. J., Carpenter, L. J., Rickard, A. R., and Monks, P. S.: Direct evidence for coastal iodine particles from laminaria macroalgae - linkage to emissions of molecular iodine, Atmos. Chem. Phys., 4, 701-713, 2004,

http://www.atmos-chem-phys.net/4/701/2004/.

Mossinger, J. C., Shallcross, D. E., and Cox, R. A.: Uv-Vis absorption cross-sections and atmospheric lifetimes of $\mathrm{CH}_{2} \mathrm{Br}_{2}, \mathrm{CH}_{2} \mathrm{I} 2$ and $\mathrm{CH}_{2} \mathrm{BrI}$, J. Chem. Soc.-Faraday Transactions, 94, 13911396, 1998.

Nightingale, P. D., Malin, G., and Liss, P. S.: Production of chloroform and other low-molecular-weight halocarbons by some species of macralgae, Limnol. Oceanogr., 40, 680-689, 1995.

Nightingale, P. D., Malin, G., Law, C. S., Watson, A. J., Liss, P. S., Liddicoat, M. I., Boutin, J., and Upstill-Goddard, R. C.: In situ evaluation of air-sea gas exchange parameterizations using novel conservative and volatile tracers, Global Biogeochem. Cy., 14, 373-387, 2000.

O’Dowd, C. D., Jimenez, J. L., Bahreini, R., Flagan, R. C., Seinfeld, J. H., Hameri, K., Pirjola, L., Kulmala, M., Jennings, S. G., and Hoffmann, T.: Marine aerosol formation from biogenic iodine emissions, Nature, 417, 632-636, 2002.

Palmer, C. J., Anders, T. L., Carpenter, L. J., Kupper, F. C., and McFiggans, G. B.: Iodine and halocarbon response of laminaria digitata to oxidative stress and links to atmospheric new particle production, Environ. Chem., 2, 282-290, 2005.

Pattey, E., Desjardins, R., Boudreau, F., and Rochette, P.: Impact of density fluctuations on flux measurements of trace gases: Implications for the relaxed eddy accumulation technique, Bound.Lay. Meteorol., 59, 195-203, 1992.

Pattey, E., Desjardins, R. L., and Rochette, P.: Accuracy of the relaxed eddy-accumulation technique, evaluated using $\mathrm{CO}_{2}$ flux measurements, Bound.-Lay. Meteorol., 66, 341-355, 1993.

Pryor, S. C., Gallagher, M., Sievering, H., Larsen, S. E., Barthelmie, R. J., Birsan, F., Nemitz, E., Rinne, J., Kulmala, M., Groenholm, T., Taipale, R., and Vesala, T. A.: review of measurement and modelling results of particle atmosphere-surface exchange, Tellus Series B, 60(1), 42-75, 2008.

Roehl, C. M., Burkholder, J. B., Moortgat, G. K., Ravishankara, A. R., and Crutzen, P. J.: Temperature dependence of UV absorption cross sections and atmospheric implications of several alkyl iodides, J. Geophys. Res.-Atmo., 102, 12819-12829, 1997.

Schery, S., Wasiolek, P., Nemetz, B., Yarger, F., and Whittlestone, S. Relaxed eddy accumulator for flux measurement of nanometersize particles, Aerosol. Sci. Technol. 28, 159-172, 1998.

Schmid, H. P.: Source areas for scalars and scalar fluxes, Bound.Lay. Meteorol., 67, 293-318, 1994. 
Simmonds, P. G. and Derwent, R. G.: Measurement of ozone and other radiatively active gases at Mace Head in the Republic of Ireland, Atmos. Environ., 25, 1795-1808, 1991.

von Glasow, R., von Kuhlmann, R., Lawrence, M. G., Platt, U., and Crutzen, P. J.: Impact of reactive bromine chemistry in the troposphere, Atmos. Chem. Phys., 4, 2481-2497, 2004,

http://www.atmos-chem-phys.net/4/2481/2004/.

Wanninkhof, R.: Relationship between wind-speed and gasexchange over the ocean, J. Geophys. Res.-Ocean., 97, 73737382, 1992.

Watson, N.: Ph. D., Chemistry, University of York, York, 15-16, 2008.

Webb, E. K., Pearman, G. I., and Leuning, R.: Correction of flux measurements for density effect due to heat and water-vapour transfer, Q. J. Roy. Meteor. Soc., 106, 85-100, 1980.

Wevill, D. J. and Carpenter, L. J.: Automated measurement and calibration of reactive volatile halogenated organic compounds in the atmosphere, Analyst, 129, 634-638, 2004.

WMO: Scientific assessment of ozone depletion 2002, World Mereorological Organization, Geneva, Switzerland, p. 498, 2003.

Yamamoto, H., Yokouchi, Y., Otsuki, A., and Itoh, H.: Depth profiles of volatile halogenated hydrocarbons in seawater in the Bay of Bengal, Chemosphere, 45, 371-377, 2001.
Yang, X., Cox, R. A., Warwick, N. J., Pyle, J. A., Carver, G. D., O'Connor, F. M., and Savage, N. H.: Tropospheric bromine chemistry and its impacts on ozone: A model study, J. Geophys. Res.-Atmos., 110, D23311, doi:10.1029/2005jd006244, 2005.

Yonge, C. M.: The Sea Shore, The Fontana New Naturalist, Collins, London/Glasgow, UK, 81-227, 1949.

Zemmelink, H. J., Gieskes, W. W. C., Klaassen, W., Beukema, W. J., de Groot, H. W., de Baar, H. J. W., Hintsa, E. J., McGillis, W. R., and Dacey, J. W. H.: Relaxed eddy accumulation measurements of the sea-to-air transfer of dimethylsulfide over the northeastern Pacific, J. Geophys. Res.-Ocean., 109, C01025, doi:10.1029/2002JL001616, 2004.

Zhou, Y., Mao, H. T., Russo, R. S., Blake, D. R., Wingenter, O. W., Haase, K. B., Ambrose, J., Varner, R. K., Talbot, R., and Sive, B. C.: Bromoform and dibromomethane measurements in the seacoast region of New Hampshire, 2002-2004, J. Geophys. Res.-Atmos., 113, D08305, doi: 10.1029/2007JD009103, 2008.

Zilitinkevich, S. S.: On the computation of basic parameters of the interaction between the atmosphere and the ocean, Tellus, 21, 17-24, 1969. 